KuLTura - мeDia- TeoLogia

ISSN 2081-8971

$2017 \mathrm{nr} 29$, s. 112-126.

\title{
Prawnokarne konsekwencje hejtu internetowego
}

Penal consequences of hate on the Internet.

\begin{abstract}
STRESZCZENIE:
W ARTYKULE AUTOR PRZEDSTAWIA ZJAWISKO ZWANE PRZEZ SOCJOLOGÓW INTERNETOWYM HEJTEM Z PERSPEKTYWY PRAWA KARNEGO. MOŻE ONO BOWIEM WYPEENIAĆ ZNAMIONA KILKU TYPÓW CZYNÓW ZABRONIONYCH W KODEKSIE KARNYM I POWODOWAĆ ODPOWIEDZIALNOŚĆ SPRAWCY. ZOSTANIE TU TAKŻE PRZEDSTAWIONA ANALIZA ZNAMION TYPÓW CZYNÓW ZABRONIONYCH, KTÓRE MOGĄ BYĆ REALIZOWANE PRZEZ HEJT INTERNETOWY - PRZESTĘPSTWA ZNIESEAWIENIA, ZNIEWAGI ORAZ ZNIEWAGI NA TLE PRZYNALEŻNOŚCI DO OKREŚLONEJ GRUPY WRAZ Z ICH TYPAMI KWALIFIKOWANYMI. AUTOR ZASTANOWI SIĘ RÓWNIEŻ NAD TYM, CZY OBECNE PRZEPISY PRAWA KARNEGO MATERIALNEGO W TYM ZAKRESIE SĄ WYSTARCZAJĄCE, CZY WYMAGAJĄ KOREKTY LEGISLACYJNEJ, ABY NALEŻYCIE CHRONIĆ DOBRA PRAWNE POKRZYWDZONYCH INTERNETOWYM HEJTEM.

\section{SEOWA KLUCZOWE:}

HEJT, INTERNET, PRAWO KARNE, ZNIEWAGA, ZNIESEAWIENIE
\end{abstract}

\begin{abstract}
:
IN THE ARTICLE THE AUTHOR WILL SHOW PHENOMENON CALLED BY THE SOCIOLOGISTS „INTERNET HATE” FROM THE PERSPECTIVE OF THE PENALTY LAW. THIS BEHAVIOR COULD FULFIL FEATURES OF MANY CRIMINAL OFFENCES PENALIZED IN THE PENAL Code ANd CAUSE CRIMINAL RESPONSIBILITY FOR A HATER. IN THE PAPER THE AUTHOR WILL ANALYZE THE FEATURES OF CRIMINAL OFFENCES A DEFAMATION, AN INSULT OR AN INSULT WHICH IS CAUSED BY PARTICIPATION IN A SPECIFIC GROUP. THE LEGAL CONSEQUENCES OF HATE ON THE INTERNET WILL BE ALSO PRESENTED. THE AUTHOR WILL ALSO CONSIDER WHICH OF THE PENALTY LAW REGULATIONS NEED CHANGE OR MAYBE LEGAL GOODS OF THE „INTERNET HATE” VICTIMS ARE PROTECTED WELL AND THE SYSTEM DOESN'T REQUIRE ANY CHANGES.
\end{abstract}

\section{KEYWORDS:}

HATE, THE INTERNET, PENALTY LAW, INSULT, DEFAMATION 
W XXI wieku wszyscy tworzymy społeczeństwo informacyjne. Cechuje się ono wysoko rozwiniętymi środkami przetwarzania informacji i komunikowania ${ }^{1}$. Wykorzystanie tych środków stanowi podstawę produkcji dochodu narodowego oraz jest źródłem utrzymania większości osób ${ }^{2}$. Podstawowe zatem zasady społeczeństwa informacyjnego obejmują wytwarzanie, przechowywanie, przetwarzanie, przekazywanie, pobieranie i wykorzystywanie informacji ${ }^{3}$. W związku z tym także i rola internauty nie ogranicza się już wyłącznie do bycia biernym obserwatorem sieci ${ }^{4}$. Stał się on aktywnym twórcą występujących w niej treści ${ }^{5}$.

\section{Hejt i trolling jako negatywne produkty kultury uczestnictwa}

Obecnie powstający nowy typ kultury, nazywany kulturą konwergencji, napędzany jest twórczością oraz współpracą użytkowników Internetu ${ }^{6}$. Mogą oni nie tylko zdobywać czy archiwizować zaprezentowane treści, ale i komentować, rozpowszechniać oraz dokonywać w nich zmian ${ }^{7}$. Kultura uczestnictwa charakteryzuje się możliwością łatwej wymiany informacji oraz nieformalną pomocniczością użytkowników ${ }^{8}$. Osoby aktywne na forach internetowych, czatach, blogach, grupach dyskusyjnych, serwisach społecznościowych, kanałach filmowych zawierają nowe znajomości, wymieniają się informacjami, przekazują doświadczenia, dzielą się zainteresowaniami ${ }^{9}$. Zagrożeniami dla tej kultury i jej uczestników, ale poniekąd także wytworami, są zjawiska mogące zakłócić te dwie charakterystyczne dla niej cechy (wymianę informacji oraz pomocniczość użytkowników) - hejt i trolling.

Marta Brzezińska-Waleszczyk zwraca uwagę na to, że słowo „hejt” jest kolokwializmem, który pochodzi ze slangu internetowego ${ }^{10}$. Według definicji słownikowej jest

1 T. Goban-Klas, P. Sienkiewicz, Społeczeństwo informacyjne: Szanse, zagrożenia, wyzwania, Kraków 1999, s. 53.

2 Tamże. Obecnie to przetwarzanie informacji stanowi źródło największych dochodów. Autorzy wskazują np. osiągnięcia Billa Gatesa, założyciela Microsoftu - firmy tworzącej oprogramowanie komputerowe, czyli operującej czystą informacją czy działalność maklerów giełdowych.

Z. E. Zieliński, Społeczeństwo informacyjne w dobie Web 2.0, http://www.ielearning.pl/wpcontent/upload/konf_wsh08.pdf (dostęp: 4.10.2017 r.).

4 A. Pomianowska-Wronka, Kultura uczestnictwa - opoka edukacji medialnej czy jej zagłada?, „Kwartalnik Nauk o Mediach” 2016, nr 1, http://knm.uksw.edu.pl/kultura-uczestnictwa-opoka-edukacji-medialnej-zaglada/ (dostęp: 3.10.2017 r.).

5 Tamże.

6 K. Stachura, Ewolucja kultury partycypacji na przykładzie serwisu YouTube, w: M. Sokołowski (red.), (Kon)teksty kultury medialnej. Analizy i interpretacje, Olsztyn 2007, s. 321. Cytowany autor zauważa, że „konwergencja i wspólne uczestnictwo często możliwe jest dzięki efektowi amalgamacji starych i nowych mediów. Treści medialne - pierwotnie emitowane w telewizji - trafiają do Internetu, nierzadko w zmodyfikowanej wersji”. - tamże, s. 324.

7 A. Pomianowska-Wronka, art. cyt.

8 Tamże.

9 Tamże.

10 M. Brzezińska-Waleszczyk, Granica pomiędzy beką a hejtem w sieci. Próba odpowiedzi na podstawie wybranych przykładów, „Kultura-Media-Teologia” 2016, nr 25, s. 82. 
nim „obraźliwy lub agresywny komentarz zamieszczony w Internecie" ${ }^{11}$. Hejtowanie polega na szyderczej i często niemerytorycznej, ale za to emocjonalnej ocenie pewnych zjawisk lub osób; znieważaniu tych osób - również przy pomocą wulgaryzmów oraz epatowaniu agresją i sianiu nienawiści ${ }^{12}$. Zachowanie to ma miejsce $w$ trakcie dyskusji internetowych na forum publicznym. Celem hejtu jest dokonanie deprecjacji określonego człowieka, poglądu czy tematu ${ }^{13}$.

Autorem pogardliwych wypowiedzi jest hejter - osoba, która czerpie przyjemność z zamieszczania w sieci negatywnych wypowiedzi ${ }^{14}$. Jego „zadaniem” jest wyrażanie niezadowolenia, krytykowanie, obrzucanie obelgami innych użytkowników Internetu, a motywacją zazdrość czy złość, wynikające często z własnych niepowodzeń życiowych ${ }^{15}$.

Można postawić tezę, iż hejt internetowy to wypowiedź zawierająca przekaz nienawiści, którego podstawą jest nietolerancja, niezależnie od tego, do jakiej grupy osób przynależy jego adresat. A zatem słowo „hejt” można stosować zamiennie z określeniem „mowa nienawiści” ${ }^{16}$. Komitet Ministrów Rady Europy zdefiniował mowę nienawiści jako „każdą formę wypowiedzi, która rozpowszechnia, podżega, propaguje lub usprawiedliwia nienawiść rasową, ksenofobię, antysemityzm lub inne formy nienawiści oparte na nietolerancji, włączając $\mathrm{w}$ to nietolerancję wyrażaną $\mathrm{w}$ formie agresywnego nacjonalizmu lub etnocentryzmu, dyskryminacji lub wrogości wobec mniejszości, migrantów, lub osób wywodzących się ze społeczności imigrantów" ${ }^{17}$. W doktrynie prawa karnego zazwyczaj przyjmuje się, iż mowa nienawiści odnosi się wyłącznie, jak wskazuje Ewa Bieńkowska, do czynów „w znamionach których znajduje się - przesądzający o ich istocie jako takich przestępstw - element (elementy), odzwierciedlający pewną cechę (cechy) charakterystyczną dla danej grupy społecznej oraz osób będących jej członkami i tylko dla nich właściwe” ${ }^{18}$. Mowę nienawiści, według autorki, stanowią także „czyny, które - co do zasady - mogą być wymierzone w kogokolwiek, choć mogą również godzić w jakąś grupę lub osobę, które zostały wybrane wyłącznie z powodu ich określonej

11 http://sjp.pwn.pl/slowniki/hejt.html_dostęp: 20.09.2016 r.).

M. Juza, Hejterstwo w komunikacji internetowej: charakterystyka zjawiska, przyczyny i sposoby przeciwdziałania, „Profilaktyka społeczna i resocjalizacja”, Warszawa 2015, s. 29; A. Naruszewicz-Duchlińska, Intencjonalne językowe zakłócenia komunikacji internetowej (trolling, flaming; hejting), „Prace językoznawcze" 2014, z. 4, s. 90.

13 A. Naruszewicz-Duchlińska, art. cyt., s. 90. M. Juza traktuje hejt jako zachowanie dewiacyjne. - taż, art. cyt., s. 29. M. Brzezińska-Waleszczyk, art. cyt., s. 83. Tamże i tamtejsze odesłania.

Por. P. Wajs, Zjawisko hejtingu i trollingu na @pontifex.pl. Analiza tweetów na profilu papieża Franciszka, „Kultura-Media-Teologia” 2016, nr 25, s. 61.

17 Załącznik do rekomendacji Komitetu Ministrów Rady Europy nr R (97) 20, przyjętej dnia 30 października 1997 r. - cyt. za A. Bodnar, A. Gliszczyńska-Grabias, R. Wieruszewski, M. Wyrzykowski, Wprowadzenie, w: A. Bodnar, A. Gliszczyńska-Grabias, R. Wieruszewski, M. Wyrzykowski (red.), Mowa nienawiści. Aspekty prawne i społeczne, LEX 2010.

18 E. Bieńkowska, Przestępstwa z nienawiści w polskim prawie karnym. Uwagi de lege lata i de lege ferenda, w: L. Mazowiecka (red.), Ofiary przestępstw z nienawiści, LEX 2013. 
specyfiki" ${ }^{19}$. Należy jednak stwierdzić, że mowa nienawiści powinna być traktowana szerzej od dotychczas przyjmowanej definicji, obejmując każdy czyn motywowany bezpodstawną, silną niechęcią, która spowodowana jest brakiem tolerancji.

Nieco innym, lecz równie negatywnym zjawiskiem, które możemy zauważyć w Internecie, jest trolling. Etymologia tego słowa ma źródło w terminologii wędkarskiej. Trolling bowiem to metoda łowienia ryb na błyszczkę ${ }^{20}$. Taką błyszczką, która ma przyciągnąć uwagę użytkowników Internetu jest komentarz trolla - wpis prowokacyjny i zazwyczaj niemerytoryczny, który tworzy szum informacyjny i zakłóca komunikację ${ }^{21}$. Troll może chcieć zmienić przebieg dyskusji lub obniżyć jej poziom ${ }^{22}$. Niektórzy z nich dokonują ataków personalnych wobec innych użytkowników, aby wszcząć kłótnię na forum $^{23}$. Trollerzy od hejterów różnią się tym, że ich głównym celem nie jest znieważenie drugiej osoby, ale sprowokowanie sporu i zaburzenie prowadzonej dyskusji. Jeżeli inny użytkownik sieci wda się w dyskusję z trollem, sprowokuje go do dalszych „psot” ${ }^{24}$.

W świetle prawa karnego działania hejtera czy trolla stanowią czyny człowieka, które mogą potencjalnie wypełniać znamiona typów czynów zabronionych. Są zatem nie tylko zachowaniem naruszającym netykietę, ale ponadto grożącym odpowiedzialnością karnąa ${ }^{25}$ W polskim prawie karnym przestępstwa powodowane nienawiścią nie są zgrupowane w jednym rozdziale Kodeksu karnego, ponieważ godzą w różne dobra prawne, a ich cechą wspólną jest jedynie motywacja sprawcy ${ }^{26}$. W niniejszym opracowaniu przedstawione zostaną prawnokarne konsekwencje wybranych i występujących najczęściej czynów hejterów, dokonywanych publicznie w ogólnodostępnych miejscach sieci Internet, uderzających w godność innych osób, opartych na bezzasadnych zarzutach i realizujących tym samym znamiona występków zniesławienia, zniewagi, bądź zniewagi na tle przynależności do określonej grupy ${ }^{27}$. Poniżej przedstawione typizacje zostaną omówione wyłącznie pod kątem zachowań hejterów. Celem publikacji jest wskazanie oraz dokonanie oceny instrumentów posiadanych przez prawo karne, pozwalających na zwalczanie tego niekorzystnego zjawiska.

Zdarzają się również hejty wyczerpujące znamiona przestępstw posiadających odmienny przedmiot ochrony, np. naruszające wolność psychiczną ${ }^{28}$. Możliwe jest rów-

19 Tamże.

20 P. Wajs, art. cyt., s. 62.

21 Tamże.

22 A. Naruszewicz-Duchlińska, art. cyt., s. 93.

23 M. Brzezińska-Waleszczyk, art. cyt., s. 62 i tamtejsze odesłania.

24 Tamże. Stąd powiedzenie w slangu internetowym - „nie karm trolla”.

25 Netykieta - zbiór zasad przyzwoitego zachowania w Internecie, swoista etykieta obowiązująca w sieci https://sjp.pl/netykieta (dostęp: 4.10 .2017 r.).

26 Ustawa z 6 czerwca 1997 r. - Kodeks karny, tj. Dz. U. 2016, poz. 1137 ze zm., zwany dalej k.k.; E. Bieńkowska, tamże.

27 W artykule tym pominięta zostanie prawnokarna ocena zachowań trollów. Zagadnienie to będzie stanowiło przedmiot odrębnych badań.

28 Art. 190 k.k. - przestępstwo groźby karalnej, art. 191a k.k. - występek tzw. stalkingu. 
nież wypełnienie przez hejtera znamion innych typów kwalifikowanych przestępstwa znieważenia, niebędących przedmiotem dalszego omówienia ${ }^{29}$. Ich konstrukcja jest podobna do typu podstawowego, którym jest występek z art. 216 k.k.

\section{Zniesławienie jako czyn hejtera internetowego}

Zachowanie hejtera może wypełniać znamiona dwóch przestępstw przeciwko czci człowieka: zniesławienia oraz zniewagi. W przypadku występku zniesławienia chroniona szczególnie jest cześć zewnętrzna, czyli założenie o uczciwości każdego człowieka, warunkujące jego prawidłowe funkcjonowanie w społeczeństwie oraz właściwe wykonywanie zawodu ${ }^{30}$. Przedmiotem ochrony występku zniewagi jest głównie część wewnętrzna, czyli poczucie własnej wartości pokrzywdzonego ${ }^{31}$. Należy uznać, że indywidualnym przedmiotem ochrony, a zarazem dobrem chronionym przez obie te typizacje jest godność człowieka, na którą składa się cześć wewnętrzna i zewnętrzna ${ }^{32}$. Zarówno zniesławienie, jak i zniewaga powodują utratę poczucia wartości człowieka w oczach własnych oraz innych ludzi.

Przestępstwo zniesławienia polega na pomówieniu przynajmniej jednego z licznych podmiotów wymienionych w art. $212 \S 1$ k.k. (m.in. osoby czy grupy osób) o takie postępowanie lub właściwości, które mogą poniżyć go w opinii publicznej lub narazić na utratę zaufania publicznego na określonym stanowisku, w danym zawodzie lub konkretnym rodzaju działalności. Przykładowo może to być oskarżenie o zachowanie sprzeczne z prawem, etyką zawodową, ogólnie pojętą moralnością, wiarą (np. w stosunku do osoby duchownej czy głęboko wierzącej); wytknięcie braku kompetencji lub zdolności; wykazanie uzależnienia, wad charakteru ${ }^{33}$. Forma, w jakiej sprawca dokona pomówienia, jest dowolna. Może to uczyć poprzez internetowy komentarz ${ }^{34}$. Sprawca znie-

29 Art. 133 k.k. - znieważenie Narodu Polskiego lub Rzeczypospolitej Polskiej, art. 135 § 2 k.k. - znieważenie Prezydenta RP, art. $136 \S 3$ i 4 k.k. - znieważenie przedstawiciela obcego państwa, art. 226 § 1 i 3 k.k. znieważenie funkcjonariusza publicznego lub konstytucyjnego organu państwa.

J. Długosz, Komentarz do art. 212 k.k. w: M. Królikowski, R. Zawłocki (red.), Kodeks karny. Część szczególna. Tom I. Komentarz. Art. 117 - 221, Warszawa 2013, s. 800. Ten rodzaj czci nazywa "zewnętrzną" S. Hypś - tenże, Komentarz do art. 212 k.k. w: A. Grześkowiak, K. Wiak (red.), Kodeks karny. Komentarz, Warszawa 2015, s. 1076.

31 Np. Sławomir Hypś cześć wewnętrzną określa jako „ochronę szacunku, dobrego imienia i godności pokrzywdzonego przed narażeniem go na negatywne odczucia jego samego”, a Joanna Długosz jako „wewnętrzne przekonanie o samym sobie”. S. Hypś, art. cyt., s. 1089; J. Długosz, art. cyt., s. 828.

Igor Zgoliński godność traktuje jako przedmiot ochrony typu z art. 216 k.k., natomiast jako dobro chronione przepisem art. 212 k.k. wskazuje dobre imię człowieka, które wypływa właśnie z godności. Tenże, Komentarz do art. 212 k.k., Komentarz do art. 216 k.k., w: V. Konarska-Wrzosek (red.). Kodeks karny. Komentarz, Warszawa 2016, s. 963, 979.

M. Kalitowski, Komentarz do art. 212 k.k., w: M. Filar (red.), Kodeks karny. Komentarz, Warszawa 2014, s. 1243; S. Hypś, Komentarz do art. 212..., art. cyt., s. 1077.

34 „Pomówienie przy tym może być wyrażone w jakikolwiek sposób, zdolny do uzewnętrznienia myśli sprawcy i przelania ich w świadomość innych osób” - wyrok Sądu Najwyższego z 20 listopada 1933, III K 1037/33, LEX 387689. 
sławienia swym zachowaniem podnosi (czyli tworzy), lub rozgłasza (rozpowszechnia istniejący) zarzut ${ }^{35}$. Fakt, czy jest prawdziwy ma znaczenie dla wyłączenia odpowiedzialności karnej hejtera poprzez tzw. dopuszczalną krytykę tylko w przypadku, gdy podnosi on lub rozgłasza go publicznie (komentarz w Internecie spełnia tę okoliczność modalną) na temat postępowania osoby pełniącej funkcję publiczną (np. złego wykształcenia wójta) lub gdy służy obronie społecznie uzasadnionego interesu (np. korupcji w celu uniemożliwienia objęcia stanowiska przez łapówkarza) ${ }^{36}$. Jeżeli natomiast zarzut dotyczy życia prywatnego lub rodzinnego, to dowód prawdy może być przeprowadzony tylko wtedy, gdy ma to zapobiec niebezpieczeństwu dla życia lub zdrowia człowieka albo demoralizacji małoletniego (np. oskarżenie o skłonności pedofilskie nauczyciela).

Problem w doktrynie wywołuje zagadnienie, czy przedmiotem pomówienia może być tylko przedstawienie faktów czy również ocen, np. hejter napisze, że w jego opinii X jest leniwy i nie nadaje się do pracy na pełnionym stanowisku ${ }^{37}$. Lech Gardocki uważa, iż „pomawianie w rozumieniu art. 212 k.k. musi mieć charakter wypowiedzi o faktach, a nie czystej oceny, ponieważ oceny nie mogą być sprawdzane przez dowód prawdy przewidziany w art. 213 k.k." ${ }^{38}$. Nie jest to do końca słuszne stwierdzenie, ponieważ oceny w mniejszym lub większym stopniu opierają się na faktach, które mogą być sklasyfikowane jako prawdziwe bądź fałszywe ${ }^{39}$. Zawężenie kryminalizacji zniesławienia tylko do pomówień, mających charakter wypowiedzi o faktach, stanowiłoby zbyt duże ograniczenie ochrony pokrzywdzonych poniżonych tymi ocenami w oczach innych. Jeżeli opinia nie jest wystarczająco podbudowana faktami lub, gdy niemożliwa jest jednoznaczna ocena ich prawdziwości bądź fałszywości, nie powinno stawiać się hejterowi zarzutu zniesławienia w momencie, w którym zarzut dotyczy postępowania osoby pełniącej funkcję publiczną albo służy obronie społecznie uzasadnionego interesu ${ }^{40}$. Gdy zarzut nie dotyczy natomiast sytuacji opisanych w dopuszczalnej krytyce (art. 213 k.k.), dla odpowiedzialności karnej owego sprawcy nie ma znaczenia to, czy posłużył się faktem, czy tylko opinią nawet, jeśli nie była wystarczająco oparta na faktach. Wtedy bowiem nie występuje potrzeba dokonywania dowodu prawdy.

Pomawiający musi dokonać swego czynu wobec innej osoby niż pokrzywdzony, co tym bardziej jest charakterystyczne dla działalności hejterów ${ }^{41}$. Zniesławienie przez hejt internetowy jest przestępstwem popełnionym publicznie, tzn. w miejscu dostępnym dla nieograniczonej liczby ludzi, co jest istotne w związku z omówioną powyżej in-

35 Wynika to z brzmienia art. $213 \S 2$ k.k. - J. Długosz, Komentarz do art. 212..., art. cyt., s. 802.

36 Przykład J. Długosz, tamże, s. 820.

37 Rozbieżność zdań prezentuje przykładowo J. Sobczak - tenże, Komentarz do art. 212 k.k, w: R. Stefański (red.), Kodeks karny. Komentarz, Warszawa 2015, s. 1389-1392.

38

39 1392.

40 A także, gdy jest uczyniony niepublicznie. Uwaga ta jednakże nie dotyczy problematyki hejtu internetowego.

41 J. Długosz, Komentarz do art. 212.... art. cyt., s. 803. 
stytucją dopuszczalnej krytyki. To przestępstwo formalne nie musi bowiem wystąpić skutek w postaci poniżenia pokrzywdzonego wopinii publicznej - samo działanie sprawcy stanowi karalne narażenie pokrzywdzonego na utratę czci.

Przestępstwo zniesławienia ma charakter powszechny i może je popełnić każda osoba, mogąca potencjalnie podlegać odpowiedzialności karnej. Strona podmiotowa charakteryzuje się umyślnością w obu postaciach - zarówno zamiarem bezpośrednim, gdy sprawca chce poniżyć kogoś w oczach innych lub w wyjątkowych okolicznościach z zamiarem ewentualnym, kiedy tylko godzi się na taką możliwośćc ${ }^{42}$.

\section{Zniewaga jako czyn hejtera internetowego}

Hejter dokonuje publicznej zniewagi drugiej osoby poprzez czyn ubliżający jej, poniżający ją, naruszający godność osobistą. Znieważające zachowanie to takie, które na podstawie przyjętych w danej kulturze i grupie społecznej zasad, odbierane jest jako uwłaczające godności drugiej osoby ${ }^{43}$. Zniewaga ma charakter obiektywny, jest przestępstwem formalnym. Zachowanie sprawcy tego typu musi polegać na użyciu takich sformułowań, które w społeczeństwie (określenia powszechnie uznawane za wulgarne inwektywy) lub w danym środowisku uznawane są za obelżywe ${ }^{44}$. Skutek w postaci odczucia psychicznego obrazy pokrzywdzonego nie należy do znamion omawianego występku ${ }^{45}$.

Zniewaga od zniesławienia różni się treścią zarzutu. W przypadku zniesławienia ma on na celu poniżenie osoby w oczach innych lub narażenie jej na utratę zaufania, natomiast istotą znieważenia jest wyłącznie „zranienie uczuć osobistych pokrzywdzonego" ${ }^{46}$.

Występek zniewagi możne popełnić każdy człowiek (przestępstwo powszechne), wyłącznie umyślnie w obu postaciach zamiaru, gdyż doktryna dopuszcza wystąpienie dolus eventualis ${ }^{47}$. Jednakże, na co zwraca uwagę Andrzej Marek, „znieważenie kogoś

42 Np. jak podaje J. Sobczak, gdy zarzut podnoszony jest w formie żartu, przy czym sprawca nie wyklucza, że jego wypowiedź może być odebrana na serio, tenże, Komentarz do art. 212..., art. cyt., s. 1414. Tak samo, gdy sprawca ma wątpliwości co do prawdziwości zarzutu, który podnosi.

S. Hypś, Komentarz do art. 216 k.k, w: A. Grześkowiak, K. Wiak (red.), Kodeks..., dz. cyt., s. 1089 i tamtejsze odesłania.

44 Np. określenie „rzeźnik” w środowisku lekarzy - przykład za: J. Piórkowską-Flieger, taż, Komentarz do art. 216 k.k, w: T. Bojarski (red.), Kodeks karny. Komentarz, Warszawa 2013, s. 591. Liczne przykłady słów znieważających w określonych środowiskach podaje również J. Sobczak” tenże, Komentarz do art. 216 k.k. w: R. Stefański (red.), Kodeks..., dz. cyt., s. 1468-1469.

Tzn. pokrzywdzony nie musi poczuć się „dotknięty” zachowaniem sprawcy. Pomimo prywatnoskargowego trybu ścigania ma to istotne znaczenie w związku z normą art. $60 § 1$ ustawy z 6 czerwca 1997 r. Kodeks postępowania karnego, tj. Dz. U. 2016, poz. 1749 ze zm., zwanej dalej k.p.k., która dopuszcza wszczęcie postępowania ściganego z oskarżenia prywatnego przez prokuratora ze względu na interes społeczny. Taki przypadek może nastąpić wtedy, gdy znieważona zostanie powszechnie znana i szanowana osoba, która sama nie czując się obrażona, nie zdecyduje się złożyć prywatnego aktu oskarżenia. S. Hypś, Komentarz do art. 216..., art. cyt., s. 1089.

47 Np. S. Hypś, tamże, s. 1091; J. Długosz, Komentarz do art. 216 k.k., w: M. Królikowski, R. Zawłocki (red.), Kodeks..., dz. cyt., s. 832; M. Kalitowski, Komentarz do art. 216 k.k., w: M. Filar (red.), Kodeks..., dz. cyt., 
jest w zasadzie zachowaniem intencjonalnym"48. Nie można jednak odmówić racji Januszowi Raglewskiemu, który uważa, że przepis art. $216 \S 1$ k.k. nie wymaga, aby sprawca działał w określonym celu - jest tylko sformułowanie „w zamiarze” ${ }^{49}$. Michał Kalitowski słusznie konstatuje, że „zamiar ewentualny zachodzi wtedy, gdy sprawca godzi się na to, że używane przez niego pod adresem innej osoby słowa (...) mogą być znieważające" ${ }^{50}$. Jest to jednak rzadkością zwłaszcza w odniesieniu do działalności internetowych hejterów, którzy swoim zachowaniem bezpośrednio dążą do ubliżenia ofierze.

Ciekawym aspektem jest możliwość poniesienia odpowiedzialności przez hejtera wtedy, gdy posłuży się on określeniem, które tylko w jego mniemaniu zawiera znieważające treści ${ }^{51}$. Będzie to stanowiło tzw. usiłowanie nieudolne, ze względu na użycie środka nienadającego się do popełnienia czynu zabronionego (art. 13 § k.k.). W tym wypadku ustawodawca sugeruje ukaranie samego złego zamiaru sprawcy, któremu nie udało się zrealizować znamion typu czynu zabronionego, z przyczyn leżących po jego stronie. W takiej sytuacji sąd jednak na mocy art. $14 \S 2$ k.k. może zastosować nadzwyczajne złagodzenie kary bądź odstąpić od jej wymierzenia.

Jeżeli pokrzywdzony internetowym hejtem odpowiedział w bliskim okresie zniewagą wzajemną (np. odpisując na obraźliwy komentarz), to nie zostaje zwolniony z konieczności ponoszenia odpowiedzialności karnej za swój czyn; niemniej jednak na podstawie art. $216 \S 3$ k.k. sąd może odstąpić od wymierzenia kary. Jest to tzw. prawo retorsji.

\section{Zniesławienie i zniewaga za pomocą środków masowego komunikowania}

Normy z art. $212 \S 2$ k.k. oraz z art. $216 \S 2$ k.k. wprowadzają typy kwalifikowane omawianych występków, polegające na ich dokonaniu za pomocą środków masowego komunikowania się. Jak zaznacza Jacek Sobczak, „Internet jest szczególnym środkiem masowego komunikowania się ze względu na swój ogólnoświatowy zasięg oraz łatwość dostę-

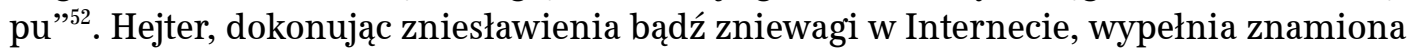
zarówno typów podstawowych tych przestępstw, jak i wymienionych wyżej typów kwalifikowanych, lecz zgodnie z zasadą specjalności ten pomijalny zbieg przepisów rozstrzygnięty zostaje na rzecz występków z art. $212 \S 2$ k.k. oraz $216 \S 2$ k.k. Momentem popełnienia czynu zabronionego będzie chwila umieszczenia w Internecie wpisu zawierającego zabronione treści ${ }^{53}$. Kluczowe dla przypisania odpowiedzialności za te typy kwalifikowane jest to, aby treść zniesławiająca lub znieważająca zamieszczona była w miejscu

\section{s. 1252.}

A. Marek, Kodeks karny. Komentarz, Warszawa 2010, s. 407.

J. Raglewski, Komentarz do art. 216 k.k., w: A. Zoll (red.), Kodeks karny. Część szczególna. Komentarz, T.

II, Komentarz do art. 111-277 k.k., Warszawa 2008, s. 841.

. Kalitowski, Komentarz do art. 216..., art. cyt., s. 1252.

J. Sobczak, Komentarz do art. 212..., art. cyt., s. 1417.

53 Tak też Sąd Najwyższy w postanowieniu z 29 czerwca 2010 r., I KZP 7/10, LEX 583984. Inaczej uważa M. Kornak, traktując zniesławienie lub zniewagę popełnione w Internecie jako przestępstwo trwałe. Tenże, Glosa do postanowienia SN z dnia 29 czerwca 2010 r., I KZP 7/10, LEX/el. 2010, 121615. 
powszechnie dostępnym w Internecie, np. komentarz na stronie www czy na ogólnodostępnym czacie, a nie w prywatnej korespondencji bądź zamkniętej grupie ${ }^{54}$. Wymagana jest bowiem „masowość” środka komunikacji, możliwość dotarcia treści do nieograniczonej liczby osób. Jeżeli znamię to zostanie spełnione, hejterowi grozi kara grzywny, ograniczenia wolności albo pozbawienia wolności do roku.

Sąd w przypadku skazania za omawiane typy kwalifikowane może orzec nawiązkę (w wysokości nawet do 100000 zł) na rzecz pokrzywdzonego, Polskiego Czerwonego Krzyża albo na inny cel społeczny wskazany przez pokrzywdzonego. W przypadku przestępstwa zniesławienia, sąd może orzec nawiązkę także przy skazaniu za typ podstawowy.

Za Witoldem Kuleszą należy powtórzyć uzasadnienie surowszego wymiaru kary dla osób zniesławiających i znieważających za pomocą środków masowego komunikowania się - jest to chęć wyrównania szans jednostki pragnącej ochrony swojej godności w starciu ze sprawcą działającym poprzez te środki, a zatem mającym większą ,siłę rażenia" ${ }^{55}$. W związku z tym społeczna szkodliwość czynów dokonywanych za pomocą środków masowego komunikowania się jest znaczna i występuje silniejsza potrzeba ochrony pokrzywdzonych.

\section{Zniewaga na tle przynależności do określonej grupy}

Norma art. 257 k.k. wprowadza szczególny typ kwalifikowany przestępstwa zniewagi oraz naruszenia nietykalności cielesnej, którym jest publiczne znieważenie albo naruszenie nietykalności cielesnej grupy ludności lub poszczególnej osoby z powodu jej przynależności narodowej, etnicznej, rasowej, wyznaniowej albo z powodu jej bezwyznaniowości, zagrożone karą pozbawienia wolności do lat 3 . Znamieniem odróżniającym ten występek od zniewagi w typie podstawowym jest szczególny status ofiary jako osoby należącej do wyszczególnionej przez ustawodawcę grupy. Pamiętać należy, iż znieważenie jej członka w sytuacji, w której nie jest ono spowodowane jego przynależnością do niej, nie wypełnia znamion tego typu kwalifikowanego.

Bliższym przedmiotem ochrony przepisu art. 257 k.k. jest godność człowieka połączona z jego wolnością od nietolerancji i prześladowań, a dalszym - porządek publicz$n^{56}$. Już w tym miejscu należy przedstawić uwagę de lege ferenda, aby ustawodawca uzupełnił katalog chronionych tą normą podmiotów o osoby posiadające odmienną orientację seksualną.

54 J. Długosz, Komentarz do art. 212..., art. cyt., s. 810.

55 W. Kulesza, Zniesławienie i zniewaga. Ochrona czci i godności w polskim prawie karnym - zagadnienia podstawowe, Warszawa 1984, s. 131.

56 Odwrotną kolejność przewiduje Aneta Michalska-Warias: taż, Komentarz do art. 257 k.k., w: M. Królikowski, R. Zawłocki (red.), Kodeks karny. Część szczególna. Tom II. Komentarz. Art. 222-317, Warszawa 2013, s. 338-339; zaś Dagmara Gruszecka sugeruje, że „dobrem prawnym jest cześć i nietykalność cielesna człowieka, rozpatrywana jednak nie tyle $\mathrm{w}$ aspekcie indywidualnym, ale w odniesieniu do funkcjonowania całego porządku publicznego, którego filarem jest pluralizm oraz respektowanie podstawowych praw i wolności innych osób, a przez to zwalczanie wszelkich form prześladowań, nietolerancji i wykluczenia społecznego". Taż, Komentarz do art. 257 k.k., w: J. Giezek (red.), Kodeks karny. Część szczególna. Komentarz, Warszawa 2014, s. 919. 


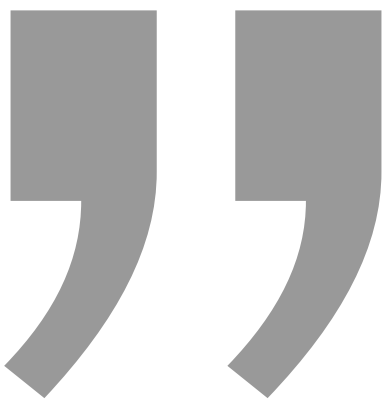

\section{Norma art. 257 k.k. wprowadza szczególny typ} kwalifikowany przestępstwa zniewagi oraz naruszenia nietykalności cielesnej, którym jest publiczne znieważenie albo naruszenie nietykalności cielesnej grupy ludności lub poszczególnej osoby z powodu jej przynależności narodowej, etnicznej, rasowej, wyznaniowej albo z powodu jej bezwyznaniowości, zaǵrożone karą pozbawienia wolności do lat 3.

W przypadku tego typu kwalifikowanego zniewagi przedstawiciele doktryny są o wiele bardziej radykalni przy dokonywaniu oceny strony podmiotowej i w większości uznają, że występek ten można popełnić wyłącznie w zamiarze bezpośrednim, i to kierunkowym (dolus directus coloratus) ${ }^{57}$. Słusznym jest jednak opowiedzieć się za poglądem wyrażonym przez mniejszość karnistów i uznać, że przestępstwo to może zostać dokonane także w zamiarze ewentualnym, tak jak w przykładzie Zbigniewa Ćwiąkalskiego, gdy sprawca „wypowiadając się publicznie (...) używa słów, co do których przypuszcza, iż mogą mieć obraźliwy charakter dla określonej grupy etnicznej" ${ }^{58}$. Hejter, używając określonego stwierdzenia, może nie chcieć znieważyć danej osoby z powodu jej przynależności do danej grupy, aczkolwiek możliwość taką przewidywać i godzić się z nią ${ }^{59}$. Pod względem strony podmiotowej kwalifikowany typ zniewagi nie różni się bowiem od typu podstawowego. Tę samą zatem uwagę odnosić należy do rzadkości wystąpienia zamiaru ewentualnego w przypadku przestępstwa znieważenia w każdym jego typie.

\section{Zbieg przepisów i tryb ścigania}

Istnieje możliwość realizacji przez czyn hejtera znamion jednego, dwóch, a nawet wszystkich omówionych powyżej typów czynów zabronionych, aczkolwiek zgodnie z normą art. $11 \S 1$ k.k., ten sam czyn może stanowić tylko jedno przestępstwo. W modelowym, zarysowanym na wstępie przypadku internetowego hejtu, sprawca może zarówno zniesławić,

57 Np. A. Michalska-Warias, tamże, s. 340; D. Gruszecka, tamże, s. 921; M. Kalitowski, Komentarz do art. 257 k.k., w:. M. Filar (red.), Kodeks..., dz. cyt., s. 1370 - 1371.; M. Mozgawa, Komentarz do art. 257 k.k., w: tenże (red.), Kodeks karny. Komentarz, Warszawa 2015, s. 690.

Z. Ćwiąkalski, Komentarz do art. 257 k.k., w: A. Zoll (red.), Kodeks..., dz. cyt., s. 1183. Tak samo dolus eventualis dopuszcza J. Piórkowska-Flieger, taż, Komentarz do art. 257 k.k., w: T. Bojarski (red.), Kodeks..., dz. cyt., s. 727.

Przykładowo, posługując się słowem „murzyn” wobec osoby czarnoskórej. 
jak i znieważyć pokrzywdzonego za pomocą środków masowego komunikowania się. Wtedy na podstawie art. $11 \S 2$ k.k. zostanie skazany za jedno przestępstwo na podstawie obu zbiegających się przepisów (przykładowo z art. $212 \S 2$ k.k. i art. $216 \S 2$ k.k. w zw. z art. 11 $\S 2$ k.k.) i sąd wymierzy mu karę na podstawie przepisu przewidującego jej najsurowszy wymiar. Natomiast, jeżeli czyn sprawcy zrealizuje znamiona występku z art. 257 k.k., to w związku z zasadą specjalności nie będzie on już odpowiadał karnie za przestępstwo $\mathrm{z}$ art. $216 \S 2$ k.k. ${ }^{60}$. Poniesie wówczas odpowiedzialność samoistną za ów występek lub kumulatywną, jeżeli nie tylko znieważył ofiarę za pomocą środków masowego komunikowania się z powodu jej przynależności do określonej grupy, ale także dokonał zniesławienia. Wymiar kary będzie wtedy określał przepis art. 257 k.k. ${ }^{61}$.

Pociąganie do odpowiedzialności karnej hejterów internetowych jest trudne ze względu na anonimowość, którą gwarantuje Internet. Zgodnie z przepisem art. 18 ust. 6 ustawy z 18 lipca 2002 r. o świadczeniu usług drogą elektroniczną, usługodawca, świadczący usługi drogą elektroniczną, jest zobowiązany nieodpłatnie udostępnić dane ich usługobiorcy ( $w$ tym imię i nazwisko, numer PESEL, adres zameldowania, adres elektroniczny) organom państwa uprawnionym na podstawie odrębnych przepisów na potrzeby prowadzonych przez nie postępowań ${ }^{62}$. Kwalifikowany występek zniewagi z art. 257 k.k. jest przestępstwem ściganym z oskarżenia publicznego, zatem organy prowadzące postępowanie karne będą mogły, powołując się na powyższy przepis, uzyskać dane, ułatwiające wykrycie hejtera.

Zarówno występek zniesławienia, jak i zniewagi są ścigane z oskarżenia prywatnego (art. $212 \S 4$ i $216 \S 5$ k.k.) ${ }^{63}$. Oznacza to, że akt oskarżenia zasadniczo może zostać wniesiony tylko przez pokrzywdzonego. Winien on także samodzielnie zebrać dowody przeciwko oskarżonemu, a przede wszystkim ustalić, kim jest anonimowy hejter. Jako osoba fizyczna nie może powołać się na omawiany w powyższym akapicie przepis. Pomimo tego Naczelny Sąd Administracyjny w wyroku z 21 sierpnia 2013 r stwierdził, że pokrzywdzony może domagać się ujawnienia danych, jakie zgromadził administrator serwisu internetowego na podstawie normy art. 23 ust. 1 pkt 5 ustawy z 29 sierpnia 1997 r. o ochronie danych osobowych, która zezwala na przetwarzanie danych (w tym także na ich udostępnienie), m.in. dla prawnie usprawiedliwionych celów ${ }^{64}$. Naczelny Sąd Administracyjny zwrócił uwagę, że podmiot żądający udostępnienia danych, będzie mu-

60 To samo dotyczy pozostałych typów kwalifikowanych przestępstwa znieważenia - zob. przypis 29. Szczególny typ kwalifikowany zniewagi stypizowany poza art. 216 k.k. na zasadzie specjalności wyłącza w razie pozornego z nim zbiegu możliwość ponoszenia odpowiedzialności za przestępstwo z art. 216 k.k.

61 Co dzięki normie z art. $11 \S 3$ in fine k.k. nie stoi na przeszkodzie orzeczeniu nawiązki, którą przewiduje art. $212 \S 3$ k.k.

62 Ustawa z 18 lipca 2002 r. o świadczeniu usług drogą elektroniczną, tj. Dz. U. 2017, poz. 1219.

63 Nie dotyczy to kwalifikowanych występków zniewagi stypizowanych poza art. 216 k.k. (np. wspomnianego przestępstwa z art. 257 k.k., czy innych wymienionych w przypisie 6) - te są ścigane z oskarżenia publicznego.

64 Wyrok Naczelnego Sądu Administracyjnego z 21 sierpnia 2013 r., I OSK 1666/12, LEX nr 1391700; ustawa z 29 sierpnia 1997 r. o ochronie danych osobowych, Dz. U. 2016, poz. 922 t.j. 
siał swoje cele odpowiednio uzasadnić, a podmiot administrujący danymi (albo Generalny Inspektor Ochrony Danych Osobowych w razie złożenia skargi) stwierdzić, które dobro wymaga w danej sprawie ochrony - wolność wypowiedzi (i ochrona danych osobowych) czy ochrona dóbr osobistych ${ }^{65}$. Nie oznacza to pewnego, a przede wszystkim szybkiego udostępnienia danych osobowych potencjalnego hejtera. Najlepszym rozwiązaniem jest skorzystanie z art. 488 § 1 i 2 k.p.k. i zgłoszenie skargi pisemnie lub ustnie Policji, która na polecenie sądu dokona czynności dowodowych (w tym zwróci się o udostępnienie danych hejtera na podstawie art. 18 ust. 6 ustawy z 18 lipca 2002 r. o świadczeniu usług drogą elektroniczną) i przekaże sądowi ich wyniki

Jak należy postąpić, gdy hejt został wysłany z komputera, znajdującego się w miejscu publicznym np. w kawiarence internetowej? Zdaniem Generalnego Inspektora Ochrony Danych Osobowych, „wykorzystując dane zarejestrowane przez system nadzoru wizyjnego w zestawieniu z innymi danymi (np. dotyczących płatności przy użyciu karty kredytowej), możliwe jest zidentyfikowanie osoby korzystającej w danym czasie z danego komputera" ${ }^{\prime 6}$.

Problem rodzi ustalenie tożsamości hejtera korzystającego z publicznych stref „hot-spot”, zmiennych adresów IP, sieci anonimowych TOR, wirtualnych sieci prywatnych VPN, fałszywych adresów e-mail, itp. Wskazanie sprawy występku będzie także utrudnione wtedy, gdy wielu użytkowników korzysta z komputera domowego lub służbowego.

Z drugiej strony koniecznie trzeba zwrócić uwagę, że współcześnie niektórzy internetowi hejterzy wcale nie ukrywają swojej tożsamości. Hejty na portalach społecznościowych wysyłają osoby korzystające z oficjalnych, podpisanych imieniem i nazwiskiem oraz opatrzonych zdjęciem profili. Brak anonimowości nie odstrasza przed hejtowaniem.

\section{Zakończenie}

Kultura uczestnictwa polega na aktywnym współudziale jej uczestników w tworzeniu oraz rozpowszechnianiu wiedzy ${ }^{67}$. Cechuje się szeroko zakrojoną współpracą, a także prowadzeniem licznych debat ${ }^{68}$. Hejt internetowy uderza w obie te cechy i utrudnia funkcjonowanie tej kultury. Jest on zjawiskiem wysoce niebezpiecznym, gdyż uniewrażliwiając społeczeństwo na mowę nienawiści, może spowodować jeszcze większą krzywdę w realnym świecie ${ }^{69}$. Niezwykle trafnie stwierdził Sąd Najwyższy w postanowieniu z 7 maja 2008 r.: „Należy pamiętać, że w przypadku Internetu mamy do czynienia ze skrajną nierównością stron. (...) Masowość Internetu, jego zasięg działania - powodują, że

\footnotetext{
Tamże.

66 http://www.giodo.gov.pl/319/id_art/2258/j/pl/_dostęp 22 września 2016 r.)

67 K. Stachura, art. cyt., s. 324.

68 Tamże.

69 „Hejtowanie zmienia społeczeństwo - łamanie kolejnych barier w sieci nakręca spiralę nienawiści, powodując, że łatwiej wyrządzić krzywdę w realnym świecie”. M. Brzezińska-Waleszczyk, art. cyt., s. 82.
} 
ma on charakter wyjątkowy na tle innych środków społecznego przekazu. Krąg odbiorców zniesławiającej bądź znieważającej informacji jest niezwykle szeroki”" ${ }^{70}$. Stąd tak ważne jest skuteczne przeciwdziałanie temu zjawisku.

Ochrona ludzkiej godności przed hejtem internetowym, gwarantowana przez prawo karne materialne, jest bardzo dobra i stanowi alternatywę dla powództw cywilnych w zakresie naruszeń dóbr osobistych. W omawianym przypadku zachodzi kolizja dwóch chronionych przez porządek prawny dóbr, jakimi są wolność słowa oraz godność osobista (wolność od jej naruszeń). Nie są to wartości absolutne i choć cześć człowieka $\mathrm{w}$ większym stopniu wygrywa tę rywalizację na gruncie omawianych przepisów, to nie podlega ochronie totalnej, o czym świadczy m.in. istnienie dozwolonej krytyki czy prawa retorsji.

Dużo większy problem stanowi skuteczne egzekwowanie przepisów prawa materialnego w postępowaniu karnym. Internet gwarantuje bowiem dużą anonimowość, a ustalenie tożsamości hejtera może być wysoce utrudnione. Nawet korzystanie z prawnych możliwości przez organy prowadzące postępowanie, dotyczących uzyskania danych usługobiorcy usługi świadczonej drogą elektroniczną, nie zawsze prowadzi do wykrycia sprawcy. W przypadku, gdy tożsamość sprawcy jest znana, pociągnięcie go do odpowiedzialności karnej nie powinno przysparzać żadnych kłopotów.

Prawo karne jest ultima ratio $w$ systemie prawa państwowego. Jego zakazy powinny być egzekwowane tylko w ostateczności jako zabezpieczenie przed popełnianiem czynów społecznie szkodliwych. Państwo i organizacje społeczne w celu ograniczenia działalności hejterów powinny podjać wysiłek na płaszczyźnie edukacyjnej (np. poprzez media publiczne, kampanie społeczne, konferencje naukowe), jednoznacznie potępiając takie zachowanie $^{71}$. W przypadku hejtingu internetowego samo tylko ściganie sprawców zniesławień czy znieważeń, jest często niestety przysłowiową ”walką z wiatrakami”.

\section{BIBLIOGRAFIA}

Bodnar A., Gliszczyńska-Grabias A., Wieruszewski R., Wyrzykowski M. (red.), Mowa nienawiści. Aspekty prawne i społeczne, LEX 2010.

Bojarski T. (red.), Kodeks karny. Komentarz, Warszawa 2013.

Brzezińska-Waleszczyk M., Granica pomiędzy beką a hejtem w sieci. Próba odpowiedzi na podstawie wybranych przykładów, „Kultura-Media-Teologia" 2016, nr 25.

Filar M. (red.), Kodeks karny. Komentarz, Warszawa 2014.

Gardocki, Prawo karne, Warszawa 2015.

Giezek J, (red.), Kodeks karny. Część szczególna. Komentarz, Warszawa 2014.

70 Postanowienie Sądu Najwyższego z 7 maja 2008 r., III KK 234/07, LEX nr 444478.

71

Co jest trudne zwłaszcza wtedy, gdy na światło dzienne wychodzą podejrzenia o korzystanie z usług „,zawodowych hejterów" przez partie polityczne w trakcie kampanii wyborczej, http://www.tvn24.pl/wiadomosci-z-kraju,3/internetowi-hejterzy-czarno-na-bialym,579181.html (dostęp” 23.09.2016 r.). 
Goban-Klas T., Sienkiewicz P., Społeczeństwo informacyjne: Szanse, zagrożenia, wyzwania, Kraków 1999, s. 53.

Grześkowiak A., Wiak K. (red.), Kodeks karny. Komentarz, Warszawa 2015. http://www.giodo.gov.pl/319/id_art/2258/j/pl/_dostęp 22 września 2016 r.) http://www.tvn24.pl/wiadomosci-z-kraju,3/internetowi-hejterzy-czarno-na-bialym,579181.html, (dostęp 23 września 2016 r.)

http://sjp.pwn.pl/slowniki/hejt.html_dostęp 20 września 2016 r.)

Juza M., Hejterstwo w komunikacji internetowej: charakterystyka zjawiska, przyczyny i sposoby przeciwdziałania, „Profilaktyka społeczna i resocjalizacja”, Warszawa 2015, s. 29.

Konarska-Wrzosek V. (red.). Kodeks karny. Komentarz, Warszawa 2016.

Kornak M, Glosa do postanowienia SN z dnia 29 czerwca 2010 r., I KZP 7/10, LEX/el. $2010 \mathrm{nr} 121615$.

Królikowski M., Zawłocki R. (red.), Kodeks karny. Część szczególna. Tom I. Komentarz. Art. 117-221, Warszawa 2013.

Królikowski, R. Zawłocki (red.), Kodeks karny. Część szczególna. Tom II. Komentarz. Art. 222-317, Warszawa 2013.

Kulesza W., Zniesławienie i zniewaga. Ochrona czci i godności w polskim prawie karnym - zagadnienia podstawowe, Warszawa 1984.

Marek A., Kodeks karny. Komentarz, Warszawa 2010.

Mazowiecka L. (red.), Ofiary przestępstw z nienawiści, LEX 2013.

Mozgawa M. (red.), Kodeks karny. Komentarz, Warszawa 2015.

Naruszewicz-Duchlińska A., Intencjonalne językowe zakłócenia komunikacji internetowej (trolling, flaming, hejting), „Prace językoznawcze” 2014, z. 4, s. 90 .

Pomianowska-Wronka A., Kultura uczestnictwa - opoka edukacji medialnej, czy jej zagłada?, „Kwartalnik Nauk o Mediach” 2016, nr 1, http://knm.uksw.edu.pl/kultura-uczestnictwa-opoka-edukacji-medialnej-zaglada/ (dostęp 3 października 2017 r.).

Postanowienie Sądu Najwyższego z 7 maja 2008 r., III KK 234/07, LEX nr 444478.

Sokołowski M. (red.), (Kon)teksty kultury medialnej. Analizy i interpretacje, Olsztyn 2007.

Stefański R. (red.), Kodeks karny. Komentarz, Warszawa 2015.

Ustawa z 6 czerwca 1997 r. - Kodeks karny, tj. Dz. U. 2016, poz. 1137 ze zm.

Ustawa z 6 czerwca 1997 r. - Kodeks postępowania karnego, tj. Dz. U. 2016, poz. 1749 ze zm.

Ustawa z 29 sierpnia 1997 r. o ochronie danych osobowych, tj. Dz. U. 2016, poz. 922.

Ustawa z 18 lipca 2002 r. o świadczeniu usług drogą elektroniczną, tj. Dz. U. 2017, poz. 1219.

Wyrok Sądu Najwyższego z 20 listopada 1933, III K 1037/33, LEX 387689. 


\section{HEJT I TROLLING W SIECI}

Wyrok Naczelnego Sądu Administracyjnego z 21 sierpnia 2013 r., I OSK 1666/12, LEX 1391700.

Zieliński Z. E., Społeczeństwo informacyjne w dobie Web 2.0, http://www.ielearning.pl/wp-content/upload/konf_wsh08.pdf (dostęp 4 października 2017 r.).

Zgoliński I., Komentarz do art. 212 k.k., Komentarz do art. 216 k.k., w: V. Konarska-Wrzosek (red.). Kodeks karny. Komentarz, Warszawa 2016, s. 963, 979.

Zoll A. (red.), Kodeks karny. Część szczególna. Komentarz, T. II, Komentarz do art. 111-277 k.k., Warszawa 2008.

\section{WYKAZ SKRÓTÓW:}

Dz. U. - Dziennik Ustaw;

k.k. - Kodeks karny;

k.p.k. - Kodeks postępowania karnego;

LEX - System Informacji Prawnej wydawnictwa Wolters Kluwer;

t.j. - tekst jednolity;

ze zm. - ze zmianami;

\section{OAUTORZE:}

mgr Michał Grudecki - doktorant II roku w Katedrze Prawa Karnego i Kryminologii WPiA UŚ; uczestnik licznych ogólnopolskich konferencji prawniczych oraz interdyscyplinarnych; zainteresowany szeroko rozumianym prawem karnym, a zwłaszcza problematyką struktury przestępstwa, w szczególności zagadnieniami bezprawności i społecznej szkodliwości czynu; laureat Nagrody im. prof. Oktawii Górniok za wybitną pracę magisterską z zakresu prawa karnego materialnego obronioną $w$ UŚ w roku akademickim 2015/2016. Kontakt:michalgrudecki@gmail.com 